\title{
Antibacterial, Antioxidant, and Anticholinesterase Activities of Plant Seed Extracts from Brazilian Semiarid Region
}

\author{
Davi Felipe Farias, ${ }^{1}$ Terezinha Maria Souza, ${ }^{2}$ Martônio Ponte Viana, \\ Bruno Marques Soares, ${ }^{3}$ Arcelina Pacheco Cunha, ${ }^{4}$ Ilka Maria Vasconcelos, ${ }^{1}$ \\ Nágila Maria Pontes Silva Ricardo, ${ }^{4}$ Paulo Michel Pinheiro Ferreira, ${ }^{5,6}$ \\ Vânia Maria Maciel Melo, ${ }^{7}$ and Ana Fontenele Urano Carvalho ${ }^{7}$ \\ ${ }^{1}$ Departamento de Bioquímica e Biologia Molecular, Universidade Federal do Ceará, 60440-970 Fortaleza, CE, Brazil \\ ${ }^{2}$ Netherlands Toxicogenomics Centre, Maastricht University, Universiteitssingel 50, 6229ER Maastricht, The Netherlands \\ ${ }^{3}$ Departamento de Fisiologia e Farmacologia, Faculdade de Medicina, Universidade Federal do Ceará, \\ 60430-270 Fortaleza, CE, Brazil \\ ${ }^{4}$ Departamento de Química Orgânica e Inorgânica, Universidade Federal do Ceará, 60440-970 Fortaleza, CE, Brazil \\ ${ }^{5}$ Departamento de Ciências Biológicas, Campus Senador Helvídio Nunes de Barros, Universidade Federal do Piauí, \\ 64600-000 Picos, PI, Brazil \\ ${ }^{6}$ Programa de Pós-Graduação em Ciências Farmacêuticas, Universidade Federal do Piauí, Avenida Universitária, \\ s/n, 64049-550 Teresina, PI, Brazil \\ ${ }^{7}$ Departamento de Biologia, Universidade Federal do Ceará, Campus do Pici, 60451-970 Fortaleza, CE, Brazil
}

Correspondence should be addressed to Ana Fontenele Urano Carvalho; aurano@ufc.br

Received 9 July 2013; Accepted 28 October 2013

Academic Editor: Kazim Husain

Copyright (C) 2013 Davi Felipe Farias et al. This is an open access article distributed under the Creative Commons Attribution License, which permits unrestricted use, distribution, and reproduction in any medium, provided the original work is properly cited.

\begin{abstract}
The antimicrobial, antioxidant, and anticholinesterase activities of ethanolic seed extracts of twenty-one plant species from Brazilian semiarid region were investigated. The extracts were tested for antimicrobial activity against six bacteria strains and three yeasts. Six extracts presented activity against the Gram (-) organism Salmonella choleraesuis and the Gram (+) organisms Staphylococcus aureus and Bacillus subtilis. The MIC values ranged from 4.96 to $37.32 \mathrm{mg} / \mathrm{mL}$. The Triplaris gardneriana extract presented activity against the three species, with MIC values 18.8,13.76, and $11.15 \mathrm{mg} / \mathrm{mL}$, respectively. Five extracts presented antioxidant activity, with $\mathrm{EC}_{50}$ values ranging from $69.73 \mu \mathrm{g} / \mathrm{mL}$ (T. gardneriana) to $487.51 \mu \mathrm{g} / \mathrm{mL}$ (Licania rigida). For the anticholinesterase activity, eleven extracts were capable of inhibiting the enzyme activity. From those, T. gardneriana, Parkia platycephala and Connarus detersus presented the best activities, with inhibition values of $76.7,71.5$, and $91.9 \%$, respectively. The extracts that presented antimicrobial activity were tested for hemolytic assay against human $\mathrm{A}, \mathrm{B}$, and $\mathrm{O}$ blood types and rabbit blood. From those, only the Myracrodruon urundeuva extract presented activity (about $20 \%$ of hemolysis at the lowest tested concentration, $1.9 \mu \mathrm{g} / \mathrm{mL}$ ). Infrared spectroscopy of six representative extracts attested the presence of tannins, polyphenols, and flavonoids, which was confirmed by a qualitative phytochemical assay.
\end{abstract}

\section{Introduction}

Plants are considered natural sources of new compounds of medical and biotechnological interest, since they synthesize a large variety of bioactive compounds. An analysis into the sources of new drugs from 1981 to 2007 reveals that almost half of the drugs approved since 1994 were based on natural products. Among these, there are various examples of development of new drugs from plant sources [1]. Many researches have dedicated great effort to detect secondary metabolites with biological activities against cancer, microorganisms, tropical diseases, and others [2,3]. Well-known examples of these compounds include flavonoids, phenols and phenolic glycosides, unsaturated lactones, sulphur 
compounds, saponins, cyanogenic glycosides, and glucosinolates [4-6].

In this context, the Brazilian semiarid region is a rich and underexploited source of bioactive molecules. This area is covered mainly by xeric shrublands known as "Caatinga." This dry land vegetation grows over an area of $800,000 \mathrm{~km}^{2}$ in Northeastern Brazil, and out of 1,000 vascular plant species described many are endemic $[7,8]$. Many of these plants are used in folk medicine by local communities to treat several diseases, pointing out the potential to discover new sources of useful compounds for several applications $[9,10]$. Recently, our team has reported for seed ethanolic extracts of Brazilian Northeastern plants promising results of insecticidal activity against Aedes aegypti [11] and antiproliferative effects to tumor cell lines [12]. In order to extend our knowledge on the Brazilian semiarid vegetation, this work aimed to evaluate the presence of antimicrobial, anticholinesterase, and antioxidant activities in ethanolic seed extracts of twentyone plant species. The antimicrobial activity was performed by the agar diffusion assay using pathogenic bacteria and yeast; antioxidant activity by the DPPH radical scavenging and anticholinesterase activity were measured. In addition, a hemolytic activity assay was done for antibacterial samples to assess the effects on nontarget cells.

\section{Materials and Methods}

2.1. Plant Collection. Mature wild seeds of twenty-one plant species were harvested (at least $500 \mathrm{~g}$ of each species) during the dry period (from January 2005 to March 2008) in the semiarid region of the Ceará State, Northeastern Brazil. Plants were identified by taxonomist Dr. Edson de Paula Nunes and voucher specimens were deposited at Herbarium Prisco Bezerra (EAC) at the Federal University of Ceará (Fortaleza, Brazil). The studied species are depicted in Table 1, which shows harvest information, voucher numbers, common names, and the traditional medicinal use by local population.

2.2. Preparation of Ethanolic Seed Extracts. Seeds of freshly collected plant material were separated from other plant materials, air-dried, and ground in a laboratory mill to a moderately fine powder (particle size $\leq 0.5 \mathrm{~mm}$ ). Powdered material $(500 \mathrm{~g})$ was submitted to extraction with $99 \%$ ethanol $(1.5 \mathrm{~L})$ at room temperature $\left(25-27^{\circ} \mathrm{C}\right)$ for 3 days. The supernatant was removed and filtered through Whatman number 1 paper. After that, the initial powder sample was still submitted to two extractions, which resulted in a final volume of extract near $4.5 \mathrm{~L}$. The ethanolic extracts resulting from three consecutive extractions were mixed together then concentrated under reduced pressure in rotary evaporator until complete elimination of solvent, and stored in a freezer at $-20^{\circ} \mathrm{C}$.

A stock solution containing $50,000 \mu \mathrm{g} \cdot \mathrm{mL}^{-1}$ of each crude extract was prepared by suspending $50,000 \mathrm{mg}$ of extract in $5 \mathrm{~mL}$ of pure dimethylsulphoxide (DMSO, Aldrich, Milwaukee, WI, USA) and mixed by sonication (model RK100, Bandelin, Berlin, Germany) for $20 \mathrm{~min}$. The volume was adjusted to $1,000 \mathrm{~mL}$ with distilled water to provide assay solutions as required.

2.3. Microorganisms. Six bacterial strains were used: Staphylococcus aureus (ATCC 25923), Bacillus subtilis (ATCC 6633), Enterobacter aerogenes (ATCC 13048), Salmonella choleraesuis (ATCC 10708), Klebsiella pneumoniae (ATCC 10031), and Pseudomonas aeruginosa (ATCC 25619). These standards were obtained from the American Type Culture Collection (ATCC) (Manassas, VA, USA). The stock culture was maintained on Mueller Hinton agar (HiMedia Laboratories Pvt. Ltd., Mumbai, India) medium at $4^{\circ} \mathrm{C}$. Three pathogenic yeasts were used: Candida albicans, C. krusei, and C. tropicalis. These fungal strains were obtained from the Microbial Ecology and Biotechnology Laboratory, Biology Department of the Federal University of Ceara, Brazil. The stock cultures were maintained on Sabouraud Dextrose agar (HiMedia Laboratories Pvt. Ltd., Mumbai, India) medium at $4^{\circ} \mathrm{C}$.

2.4. Antibacterial and Antifungal Activity. The disc diffusion method was followed for antibacterial and antifungal susceptibility test as described previously [16], with some modifications. Petri dishes were prepared by pouring $20 \mathrm{~mL}$ of Mueller-Hinton agar for bacteria and Sabouraud Dextrose agar for fungi and allowed to solidify. Dishes were dried and $0.1 \mathrm{~mL}$ of standardized inoculum suspension $\left(10^{6} \mathrm{CFU} / \mathrm{mL}\right.$ for bacteria and absorbance of 0.600 at $450 \mathrm{~nm}$ for fungi) was poured and uniformly spread. The excess inoculum was drained and the inoculum was allowed to dry for $5 \mathrm{~min}$. The paper filter discs ( $7 \mathrm{~mm}$ of diameter) containing $20 \mu \mathrm{L}$ of each ethanolic extract were then applied and the dishes were incubated at $37^{\circ} \mathrm{C}$ for $18 \mathrm{~h}$ for bacterial growth and at the same temperature for $48 \mathrm{~h}$ for fungal growth. Tetracycline (30 mg/disc) was used as positive control for the antibacterial assay. Nystatin solution (100,000 IU/mL, EMS, SP, Brazil) ( $20 \mu \mathrm{L} /$ disc) was used as positive control for the antifungal assay. The inhibition zone was measured from the edge of the disc to the inner margin of the surrounding pathogens. All determinations were run in triplicate.

2.5. Minimum Inhibitory Concentration (MIC). Minimum inhibitory concentrations of the seed ethanolic extracts were tested as described previously by the twofold serial dilution method. The test extract was dissolved in 5\% DMSO to obtain $50 \mathrm{mg} \cdot \mathrm{mL}^{-1}$ stock solution. Stock solution was diluted with distilled water to achieve $45,40,35,30,25,20,15,10$, and $5 \mathrm{mg} \cdot \mathrm{mL}^{-1}$ or as required. The wet paper discs with dilutions were placed over the dish and the cultures were incubated in BOD incubators at $37^{\circ} \mathrm{C}$ for $18 \mathrm{~h}$ (bacteria) and $37^{\circ} \mathrm{C}$ for $48 \mathrm{~h}$ (yeasts). The lowest concentration, which inhibits the visible growth of tested organism after macroscopic evaluation, was determined as MIC. All determinations were run in triplicate.

2.6. Antioxidant Activity. The capacity to scavenge the 2,2diphenyl-1-picrylhydrazyl (DPPH) free radical was monitored [17]. The diluted crude extracts $(0.1 \mathrm{~mL})$ in different concentrations ( 5 to $1,000 \mu \mathrm{g} \cdot \mathrm{mL}^{-1}$ ) were mixed with $3.9 \mathrm{~mL}$ of methanolic solution containing $\mathrm{DPPH}$ radicals 


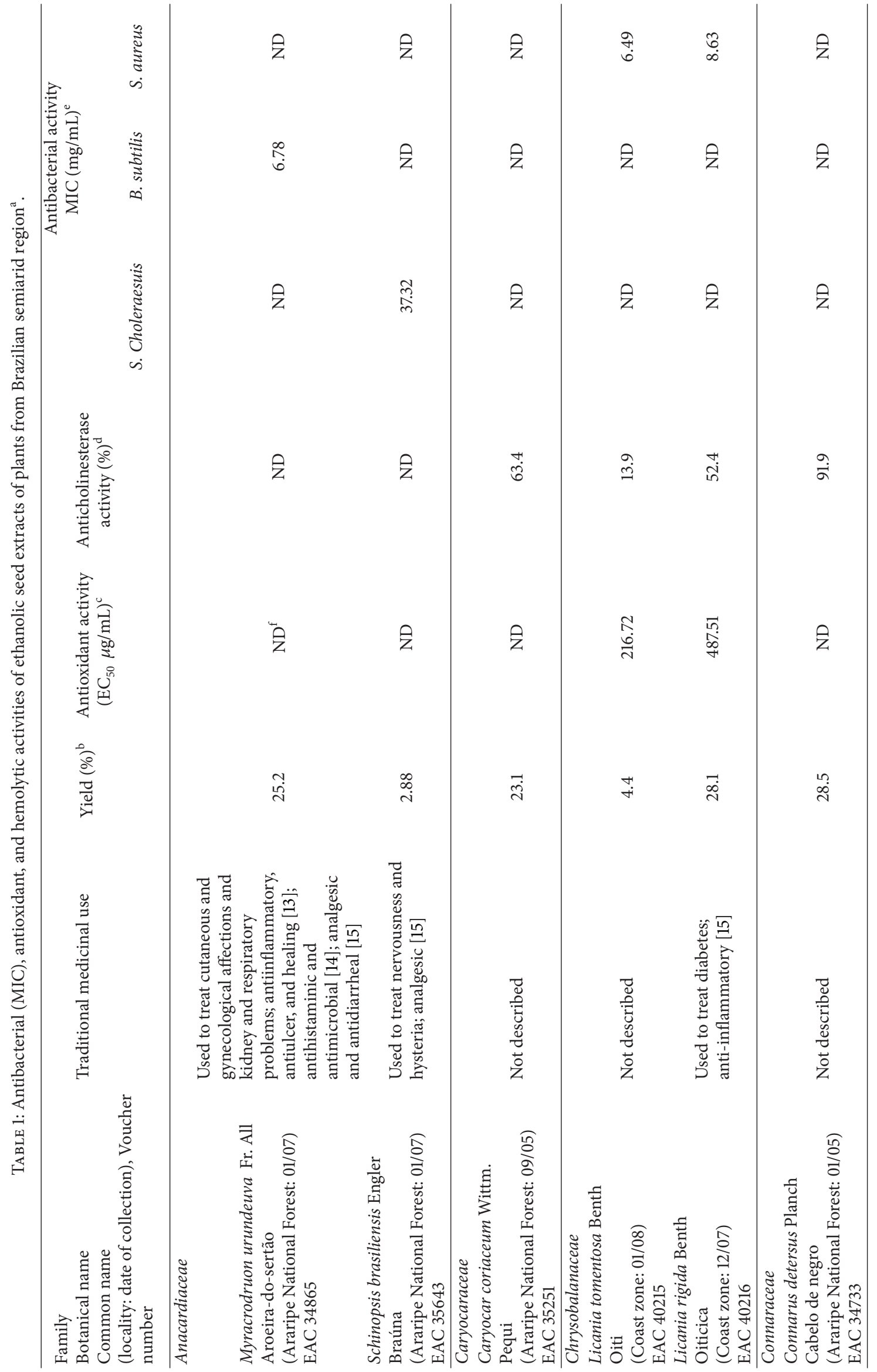




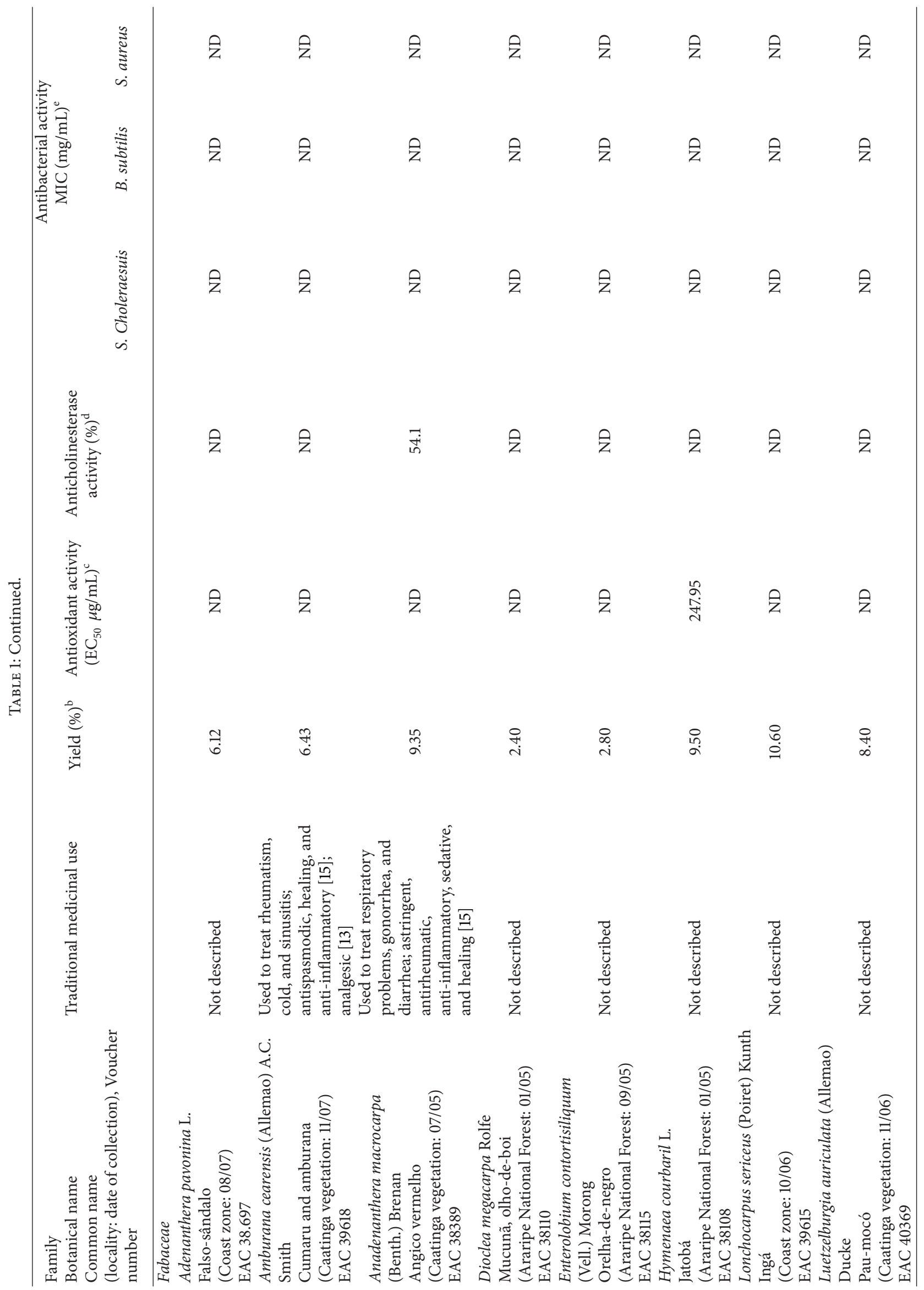




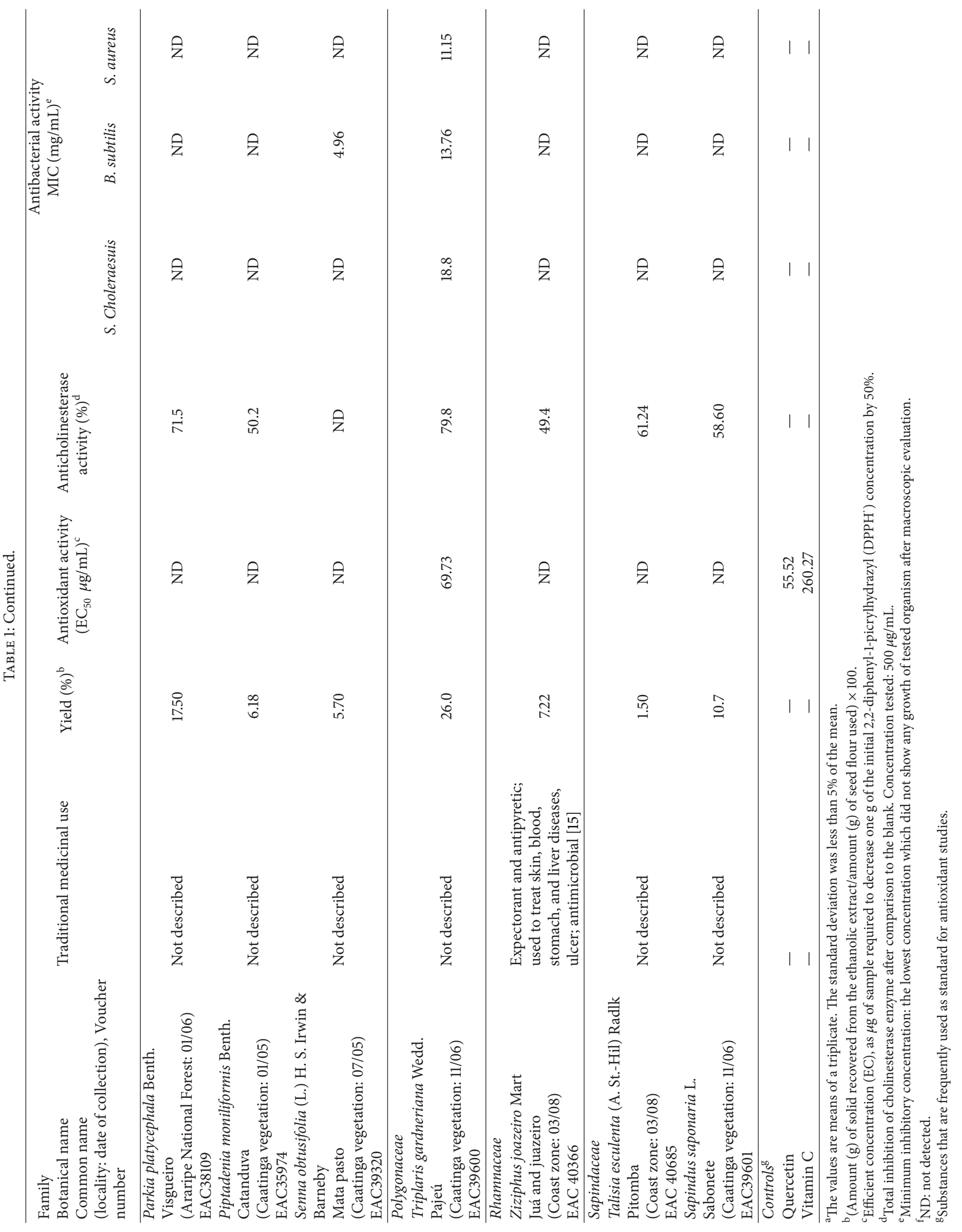


$\left(6.5 \times 10^{-1} \mathrm{~mol} \cdot \mathrm{L}^{-1}\right)$. The reduction of the $\mathrm{DPPH}$ radical was measured by monitoring continuously the decrease of absorption at $515 \mathrm{~nm}$. The percentage scavenging of the $\mathrm{DPPH}$ radical was calculated according to the following formula: \% scavenging effect $=100 \times\left[\left(A_{\mathrm{DPPH}}-\mathrm{As}\right) / A_{\mathrm{DPPH}}\right]$, where As is the absorbance of the solution when the sample has been added at a particular level and $A_{\mathrm{DPPH}}$ is the absorbance of the DPPH solution. The percentage of the remaining DPPH was plotted against the sample/standard concentration to obtain the amount of antioxidant necessary to decrease the initial concentration of DPPH by $50 \%\left(\mathrm{EC}_{50}\right)$. Based on the parameter $\mathrm{EC}_{50}$, the result was expressed in terms of $\mu \mathrm{g}$ of seed extract per $\mathrm{mL}$ of $\mathrm{DPPH}$ in the reaction medium. All determinations were run in triplicate.

2.7. Anticholinesterase Activity. The anticholinesterase activity of the ethanolic extracts was measured as described by [18], with slight modifications. Acetylcholinesterase activity was measured using a 96-well microplate reader based on Ellman's method [19]. In this method the enzyme hydrolyzes the substrate acetylthiocholine resulting in the production of thiocholine which reacts with $5,5^{\prime}$-dithiobis(2nitrobenzoic acid) (DTNB) to produce 2-nitrobenzoate-5mercaptothiocholine and 5-thio-2-nitrobenzoate which can be detected at $405 \mathrm{~nm}$. In the 96 -well plates, $25 \mu \mathrm{L}$ of $15 \mathrm{mM}$ acetylthiocholine iodide (ATCI) in water, $125 \mu \mathrm{L}$ of $3 \mathrm{mM}$ DTNB in $50 \mathrm{mM}$ Tris- $\mathrm{HCl}$ buffer containing $0.1 \mathrm{M} \mathrm{NaCl}$ and $0.02 \mathrm{M} \mathrm{MgCl}_{2} \cdot 6 \mathrm{H}_{2} \mathrm{O}, 50 \mu \mathrm{L}$ of $50 \mathrm{mM}$ Tris- $\mathrm{HCl}$ buffer containing $0.1 \% \mathrm{BSA}$, and $25 \mu \mathrm{L}$ of plant extract sample $\left(5 \mathrm{mg} \cdot \mathrm{mL}^{-1}\right.$ in $\mathrm{MeOH}$ diluted ten times with $50 \mathrm{mM}$ Tris$\mathrm{HCl}$ buffer to give a concentration of $0.5 \mathrm{mg} \cdot \mathrm{mL}^{-1}$ ) were added and the absorbance was measured at $405 \mathrm{~nm}$ every $30 \mathrm{~s}$ for three times. Then $25 \mu \mathrm{L}$ of $0.22 \mathrm{U} \cdot \mathrm{mL}^{-1}$ of acetylcholinesterase from electric eel was added and the absorbance was again read every $45 \mathrm{~s}$ for eight times. Any increase in absorbance due to the spontaneous hydrolysis of the substrate was corrected by subtracting the rate of the reaction before the addition of the enzyme from the rate of the enzyme reaction. The percentage of inhibition was calculated by comparison of sample rates to a blank.

2.8. Hemolytic Activity Assay. The test was performed in $1.5 \mathrm{~mL}$ microtubes following the method described by [20] with some modifications. Firstly, a twofold serial dilution of each seed ethanolic extract was prepared with $0.9 \% \mathrm{NaCl}$ ranging from 1,000 to $1.9 \mu \mathrm{g} \cdot \mathrm{mL}^{-1}$ and reserved. Then, $100 \mu \mathrm{L}$ of a $1 \%$ red blood cells $(\mathrm{A}, \mathrm{B}$, and $\mathrm{O}$ human blood types or rabbit blood) suspension was added to a new microtube containing $900 \mu \mathrm{L}$ of each seed extract dilution, which was then taken to incubator at $37^{\circ} \mathrm{C}$ for $1 \mathrm{~h}$. After that, the tubes were centrifuged at $3,000 \times \mathrm{g}$ for $5 \mathrm{~min}$. The supernatant $(200 \mu \mathrm{L})$ was placed in a 96-well plate and led to a microplate reader (Epoch, BioTek, Vermont, USA) to measure the absorbance at $540 \mathrm{~nm}$. The cell suspensions of each human blood type or those of rabbits $(100 \mu \mathrm{L})$ were mixed with distilled water or $0.9 \% \mathrm{NaCl}(900 \mu \mathrm{L})$ to obtain the absorbances for 100 and $0 \%$ of cell lysis, respectively. The percentage of hemolysis was calculated as follows: $\%$ hemolysis $=\mathrm{Abs}_{\text {test }} / \mathrm{Abs}_{p c} \times 100$, where $\mathrm{Abs}_{\text {test }}=\mathrm{Abs}_{540}$ of the $1 \%$ cell suspension treated with sample test and $\mathrm{Abs}_{p c}=\mathrm{Abs}_{540}$ of the $1 \%$ cell suspension treated with distilled water. To calculate the relation between percentage of hemolysis and seed extract concentration, the hemolytic activity was expressed as the lowest seed extract concentration $\left(\mu \mathrm{g} \cdot \mathrm{mL}^{-1}\right)$ capable of causing hemolysis $\geq 20 \%$. All determinations were run in triplicate.

2.9. Infrared Spectroscopy. The infrared spectrum was recorded from $\mathrm{KBr}$ discs on a FTIR Perkin Elmer model 16 PC spectrophotometer (PerkinElmer, Waltham, USA). Absorption maxima (Èđmax) were reported in wavenumbers $\left(\mathrm{cm}^{-1}\right)$. The spectra were used to determine organic groups indicative of the main classes of secondary metabolites.

2.10. Phytochemical Study. The ethanolic seed extracts were screened for phytochemical compounds such as phenols and tannins (reaction with ferric chloride), leucoanthocyanidins (heat treatment followed by alkalinization and acidification of sample), flavonoids and xanthones (reaction of magnesium granules with hydrochloric acid), steroids and triterpenes (extraction with chloroform, acetic anhydride, and sulfuric acid), saponins (foam production after water solubilization and stirring), and alkaloids (precipitation with Hager, Mayer, and Dragendorff reagents) [21]. These analyses were based on visual observation of color modification or precipitate formation after addition of specific reagents.

\section{Results and Discussion}

The ethanolic seed extracts did not show activity against the Gram (-) organisms E. aerogenes, K. pneumonia, and $P$. aeruginosa nor against the yeasts C. albicans, C. krusei, and $C$. tropicalis. MIC values obtained against the Gram (+) organisms $S$. aureus and B. subtilis, and the Gram (-) organism $S$. choleraesuis are shown in Table 1. Among all samples tested and microorganisms used, the seed extract of S. obtusifolia presented the lowest MIC value $\left(4.96 \mathrm{mg} \cdot \mathrm{mL}^{-1}\right)$ against the pathogenic bacteria S. aureus. However, the species T. gardneriana showed the broadest spectrum of activity, being active against $B$. subtilis, S. choleraesuis, and S. aureus with MIC values of $18.8,13.76$, and $11.15 \mathrm{mg} \cdot \mathrm{mL}^{-1}$, respectively. Although there are a great number of studies reporting antimicrobial activity of plant parts like leaves, roots and stems, antimicrobial screenings using specifically seed extracts are very rare. The reason for that is not easy to explain, since seeds are admittedly a rich source of compounds involved in plant defense [22]. A good example is the seed extract of Bixa orellana that has been described to have antimicrobial activity against six strains of bacteria, among these are $B$. subtilis, $S$. aureus and $P$. aeruginosa, and against the yeast C. albicans [23]. Likewise, guarana (Paullinia cupana) seed extracts presented strong antimicrobial activity against a huge number of damaging fungi and bacteria [24]. As to the potency of the antibacterial activities observed, these were much lower than those described for Syzygium jambolanum seed extracts against the same bacterial strains used in this work (MIC values ranging from 0.06 to $0.25 \mathrm{mg} \cdot \mathrm{mL}^{-1}$ ), even 
when compared to the best result observed as described above for S. obtusifolia (MIC $4.96 \mathrm{mg} \cdot \mathrm{mL}^{-1}$ ). In addition, the $S$. jambolanum seed extracts were also effective against damaging-fungi strains. The low potency of the ethanolic seed extracts could be due to the chemical composition of the samples, with low concentration of antimicrobial substances. In fact, the results of phytochemical study revealed that all seed extracts with activity against bacteria showed in their composition classes of secondary metabolites widely known as efficient antimicrobial compounds (alkaloids, flavones, flavonoids, phenols, saponins, and tannins) [25]. A fractionation of these samples in a polarity gradient could improve their activities. Therefore, the absence or low activity of the seed extracts could be a problem of concentration.

The hemolytic activity assay was performed with the seed extracts that were active against the microorganisms used. Among six species tested, only M. urundeuva caused hemolysis in all blood types ( $1 \%$ erythrocytes suspension of $\mathrm{A}, \mathrm{B}$, and $\mathrm{O}$ human blood types and rabbit blood) employed, being the lowest concentration tested $\left(1.9 \mu \mathrm{g} \cdot \mathrm{mL}^{-1}\right)$ capable of causing more than $20 \%$ hemolysis. These results show that although the antimicrobial extracts are not very potent, they are more specific to bacterial cells, except for M. urundeuva seed extract. It is well reported that some classes of plant secondary metabolites are potent hemolytic compounds [26], such as phenols that were also detected for M. urundeuva seed extract in the phytochemical study.

The results for antioxidant capacity are also shown in Table 1. Only five seed extracts were able to capture free radicals in the concentrations used according to DPPH method; these were Hymenaea courbaril $\left(\mathrm{EC}_{50} 247.95 \mu \mathrm{g} \cdot \mathrm{mL}^{-1}\right), L$. rigida $\left(487.51 \mu \mathrm{g} \cdot \mathrm{mL}^{-1}\right)$, L. tomentosa $\left(216.72 \mu \mathrm{g} \cdot \mathrm{mL}^{-1}\right)$, and T. gardneriana $\left(69.73 \mu \mathrm{g} \cdot \mathrm{mL}^{-1}\right)$. The L. tomentosa and T. gardneriana seed extracts were more potent than the positive control vitamin $\mathrm{C}\left(\mathrm{EC}_{50} 260.27 \mu \mathrm{g} \cdot \mathrm{mL}^{-1}\right)$ and the second one was just a bit less potent than quercetin $\left(\mathrm{EC}_{50} 55.52 \mu \mathrm{g} \cdot \mathrm{mL}^{-1}\right)$, one of the most potent antioxidant molecules. A previous study [27] showed that out of 25 plant extracts (hexane, dichloromethane, and methanol), only 12 presented some radical scavenging activity, and the most potent activity showed an $\mathrm{IC}_{50}$ value of $111.99 \mu \mathrm{g} \cdot \mathrm{mL}^{-1}$. This promising result for T. gardneriana could be attributed to components such as tannins, flavones, flavonoids, and especially phenols [28, 29]. Further steps of fractionation and purification may show the molecule(s) responsible for this excellent activity.

Concerning the anticholinesterase activity (Table 1), among the 21 ethanolic extracts tested, 11 presented inhibition of the cholinesterase enzyme. T. gardneriana, P. platycephala and $C$. detersus extracts presented the strongest activity, with inhibition values of, respectively, 76.7, 71.5, and 91.9\% at the final concentration of $500 \mu \mathrm{g} / \mathrm{mL}$. These values are significant when compared to those obtained in previous studies [18], which have shown inhibition values of 17 plant extracts ranging from 9 to $81 \%$ using a single concentration of $1 \mathrm{mg} / \mathrm{mL}$. Several plant-derived drugs, such as galantamine and rivastigmine, are used to inhibit $\mathrm{AChE}$ and thus increase endogenous levels of acetylcholine to improve cholinergic transmission [30]. Many studies described alkaloids as the

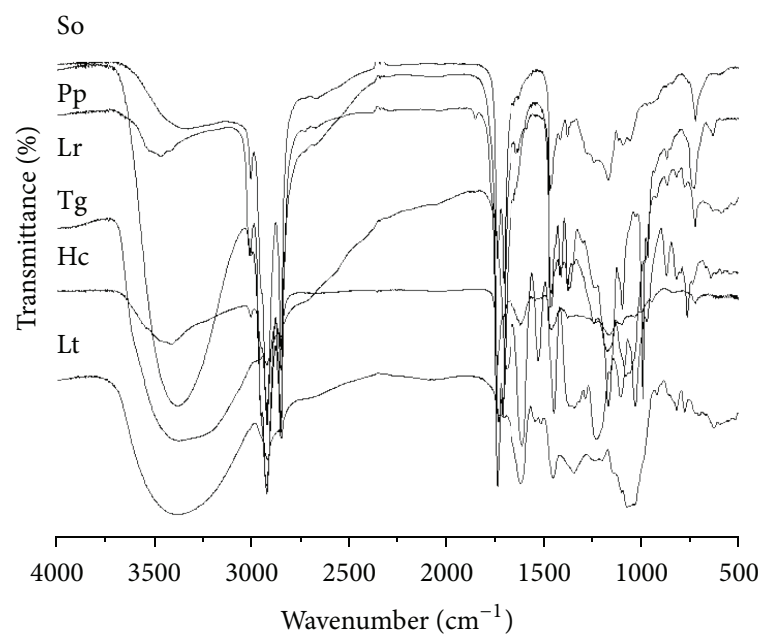

FIGURE 1: Infrared absorption spectra of some ethanolic extracts tested in this study. So: Senna obtusifolia; Pp: Parkia platycephala; Lr: Licania rigida; Tg: Triplaris gardneriana; Hc: Hymenaea courbaril; Lt: Licania tomentosa.

main compounds capable of inhibiting AChE enzyme [31], but recent studies have pointed out several new classes of secondary metabolites as potent inhibitors, such as flavonoids [32], flavones [33], and xanthones [34], as well as steroids, terpenoids, oils, and other phenolic compounds [35]. Thus, the phytochemical analysis data in the present study corroborate previous molecular findings, since polyphenols were detected in all extracts. Additionally, the extract of T. gardneriana showed the presence of chalcones and aurones. Therefore, further studies should be conducted to assess the potential of these extracts and their respective molecules to inhibit AChE enzyme and thus offer a potential to fight neurodegenerative diseases such as Alzheimer's.

After running all the assays described above infrared spectroscopy with the most promising ethanolic seed extracts was also performed (S. obtusifolia, P. platycephala, L. rigida, $L$. tomentosa, and T. gardneriana) to confirm the results of phytochemical qualitative study. The phytochemical studies with these ethanolic extracts showed the presence of tannins and flavonoids, which were confirmed by infrared spectroscopy (Figure 1). The spectra obtained, between 1,800 and $800 \mathrm{~cm}^{-1}$, are present at the fingerprint zone of aromatic compounds, which can be found in tannins, polyphenols, and flavonoids [36]. Further steps of fractionation and purification may show the molecule(s) responsible for this excellent activity.

\section{Conclusions}

This study revealed antibacterial, antioxidant, and anticholinesterase activities in some seed ethanolic extracts of Brazilian semiarid region plants, emphasizing the antioxidant activity presented by T. gardneriana seeds. This showed a potent capacity to catch free radicals by DPPH assay. This promising result could be attributed to its composition 
featuring phenols, tannins, flavones and flavonoids. New phytochemical and molecular studies are underway to identify the bioactive compound(s) responsible for this activity.

\section{Conflict of Interests}

The authors declare that there is no conflict of interests regarding the publication of this paper.

\section{Acknowledgment}

The authors thank the Ministério da Saúde, Departamento de Ciências e Tecnologia (DECIT), Secretaria de Ciências, Tecnologia e Insumos estratégicos (SCTIE), Conselho Nacional de Desenvolvimento Científico e Tecnológico (CNPq), and Fundação Cearense de Apoio Científico e Tecnológico (FUNCAP) for financial support of this research.

\section{References}

[1] C. Katiyar, A. Gupta, S. Kanjilal, and S. Katiyar, "Drug discovery from plant sources: an integrated approach," Ayu, vol. 33, pp. 1019, 2012.

[2] P. S. Luize, T. S. Tiuman, L. G. Morello et al., "Effects of medicinal plant extracts on growth of Leishmania (L.) amazonensis and Trypanosoma cruzi," Brazilian Journal of Pharmaceutical Sciences, vol. 41, no. 1, pp. 85-94, 2005.

[3] A. E. Edris, "Anti-cancer properties of Nigella spp. essential oils and their major constituents, thymoquinone and $\beta$-Elemene," Current Clinical Pharmacology, vol. 4, no. 1, pp. 43-46, 2009.

[4] R. N. Bennett and R. M. Wallsgrove, "Secondary metabolites in plant defence mechanisms," New Phytologist, vol. 127, no. 4, pp. 617-633, 1994.

[5] R. J. Grayer and J. B. Harborne, "A survey of antifungal compounds from higher plants, 1982-1993," Phytochemistry, vol. 37, no. 1, pp. 19-42, 1994.

[6] A. E. Osbourn, "Preformed antimicrobial compounds and plant defense against fungal attack," Plant Cell, vol. 8, no. 10, pp. 1821$1831,1996$.

[7] E. V. S. B. Sampaio, "Vegetação e flora da Caatinga," APNE/ CNIP: Recife, 2000.

[8] C. F. C. B. R. De Almeida, T. C. De Lima E Silva, E. L. C. De Amorim, M. B. D. S. Maia, and U. P. De Albuquerque, "Life strategy and chemical composition as predictors of the selection of medicinal plants from the caatinga (Northeast Brazil)," Journal of Arid Environments, vol. 62, no. 1, pp. 127-142, 2005.

[9] U. P. de Albuquerque, P. M. de Medeiros, A. L. S. de Almeida et al., "Medicinal plants of the caatinga (semi-arid) vegetation of NE Brazil: a quantitative approach," Journal of Ethnopharmacology, vol. 114, no. 3, pp. 325-354, 2007.

[10] U. P. de Albuquerque, V. A. da Silva, M. D. C. Cabral, N. Leal Alencar, and L. D. H. C. Andrade, "Comparisons between the use of medicinal plants in indigenous and rural caatinga (dryland) communities in NE Brazil," Boletin Latinoamericano y del Caribe de Plantas Medicinales y Aromaticas, vol. 7, no. 3, pp. 156-170, 2008.

[11] T. M. Souza, D. F. Farias, B. M. Soares et al., "Toxicity of Brazilian plant seed extracts to two strains of Aedes aegypti (Diptera: Culicidae) and Nontarget Animals," Journal of Medical Entomology, vol. 48, no. 4, pp. 846-851, 2011.
[12] P. M. P. Ferreira, D. F. Farias, M. P. Viana et al., "Study of the antiproliferative potential of seed extracts from Northeastern Brazilian plants," Anais da Academia Brasileira de Ciencias, vol. 83, no. 3, pp. 1045-1058, 2011.

[13] F. J. A. Matos, M. E. O. Matos, M. P. Sousa, M. I. L. Machado, and A. A. Craveiro, Constituintes Químicos Ativos e Propriedades Biológicas de Plantas Medicinais Brasileiras, UFC, Fortaleza, Brazil, 1st edition, 2004.

[14] F. J. A. Matos, Plantas Medicinais: Guia de Seleção e Emprego de Plantas Usadas em Fitoterapia no Nordeste do Brasil, IU, Fortaleza, Brazil, 2nd edition, 2000.

[15] G. N. Maia, Caatinga: Árvores e Arbustos e Suas Utilidades, D \& Z Computação Gráfica e Editora, São Paulo, Brazil, 1st edition, 2004.

[16] M. Chandrasekaran and V. Venkatesalu, "Antibacterial and antifungal activity of Syzygium jambolanum seeds," Journal of Ethnopharmacology, vol. 91, no. 1, pp. 105-108, 2004.

[17] B. Yepez, M. Espinosa, S. López, and G. Bolaos, "Producing antioxidant fractions from herbaceous matrices by supercritical fluid extraction," Fluid Phase Equilibria, vol. 194-197, pp. 879884, 2002.

[18] E. M. Cardoso-Lopes, J. A. Maier, M. R. Da Silva et al., "Alkaloids from stems of esenbeckia leiocarpa Engl. (Rutaceae) as potential treatment for alzheimer disease," Molecules, vol. 15, no. 12, pp. 9205-9213, 2010.

[19] G. L. Ellman, K. D. Courtney, V. Andres Jr., and R. M. Featherstone, "A new and rapid colorimetric determination of acetylcholinesterase activity," Biochemical Pharmacology, vol. 7, no. 2, pp. 88-95, 1961.

[20] A. W. Bernheimer, "Assay of hemolytic toxins," Methods in Enzymology, vol. 165, pp. 213-217, 1988.

[21] F. J. A. Matos, Introdução À Fitoquímica Experimental, Editora UFC, Ceará, Brazil, 1st edition, 2009.

[22] J. Xavier-Filho, "Sementes e suas defesas contra insetos. Projeto Multinacional de Biotecnologia e Alimentos," Organização dos Estados Americanos (OEA), pp.1-31, 1993.

[23] T. C. Fleischer, E. P. K. Ameade, M. L. K. Mensah, and I. K. Sawer, "Antimicrobial activity of the leaves and seeds of Bixa orellana," Fitoterapia, vol. 74, no. 1-2, pp. 136-138, 2003.

[24] L. Majhenič, M. Škerget, and Ž. Knez, "Antioxidant and antimicrobial activity of guarana seed extracts," Food Chemistry, vol. 104, no. 3, pp. 1258-1268, 2007.

[25] M. M. Cowan, "Plant products as antimicrobial agents," Clinical Microbiology Reviews, vol. 12, no. 4, pp. 564-582, 1999.

[26] A. Rafat, K. Philip, and S. Muniandy, "Antioxidant potential and content of phenolic compounds in ethanolic extracts of selected parts of Andrographis paniculata," Journal of Medicinal Plant Research, vol. 4, no. 3, pp. 197-202, 2010.

[27] O. M. Mosquera, Y. M. Correa, D. C. Buitrago, and J. Niño, "Antioxidant activity of twenty five plants from Colombian biodiversity," Memorias do Instituto Oswaldo Cruz, vol. 102, no. 5, pp. 631-634, 2007.

[28] N. Cotelle, J.-L. Bernier, J.-P. Catteau, J. Pommery, J.-C. Wallet, and E. M. Gaydou, "Antioxidant properties of hydroxyflavones," Free Radical Biology and Medicine, vol. 20, no. 1, pp. 35-43, 1996.

[29] H. Oh, D.-H. Kim, J.-H. Cho, and Y.-C. Kim, "Hepatoprotective and free radical scavenging activities of phenolic petrosins and flavonoids isolated from Equisetum arvense," Journal of Ethnopharmacology, vol. 95, no. 2-3, pp. 421-424, 2004. 
[30] S. López, J. Bastida, F. Viladomat, and C. Codina, "Acetylcholinesterase inhibitory activity of some Amaryllidaceae alkaloids and Narcissus extracts," Life Sciences, vol. 71, no. 21, pp. 2521-2529, 2002.

[31] M. G. Ortega, A. M. Agnese, and J. L. Cabrera, "Anticholinesterase activity in an alkaloid extract of Huperzia saururus," Phytomedicine, vol. 11, no. 6, pp. 539-543, 2004.

[32] B. J. Hillhouse, D. S. Ming, C. J. French, and G. H. N. Towers, "Acetylcholine esterase inhibitors in Rhodiola rosea," Pharmaceutical Biology, vol. 42, no. 1, pp. 68-72, 2004.

[33] P. Sawasdee, C. Sabphon, D. Sitthiwongwanit, and U. Kokpol, "Anticholinesterase activity of 7-methoxyflavones isolated from Kaempferia parviflora," Phytotherapy Research, vol. 23, no. 12, pp. 1792-1794, 2009.

[34] M.-J. R. Howes, N. S. L. Perry, and P. J. Houghton, "Plants with traditional uses and activities, relevant to the management of Alzheimer's disease and other cognitive disorders," Phytotherapy Research, vol. 17, no. 1, pp. 1-18, 2003.

[35] H.-F. Ji and H.-Y. Zhang, "Multipotent natural agents to combat Alzheimer's disease. Functional spectrum and structural features," Acta Pharmacologica Sinica, vol. 29, no. 2, pp. 143-151, 2008.

[36] K. Fernández and E. Agosin, "Quantitative analysis of red wine tannins using Fourier-transform mid-infrared spectrometry," Journal of Agricultural and Food Chemistry, vol. 55, no. 18, pp. 7294-7300, 2007. 

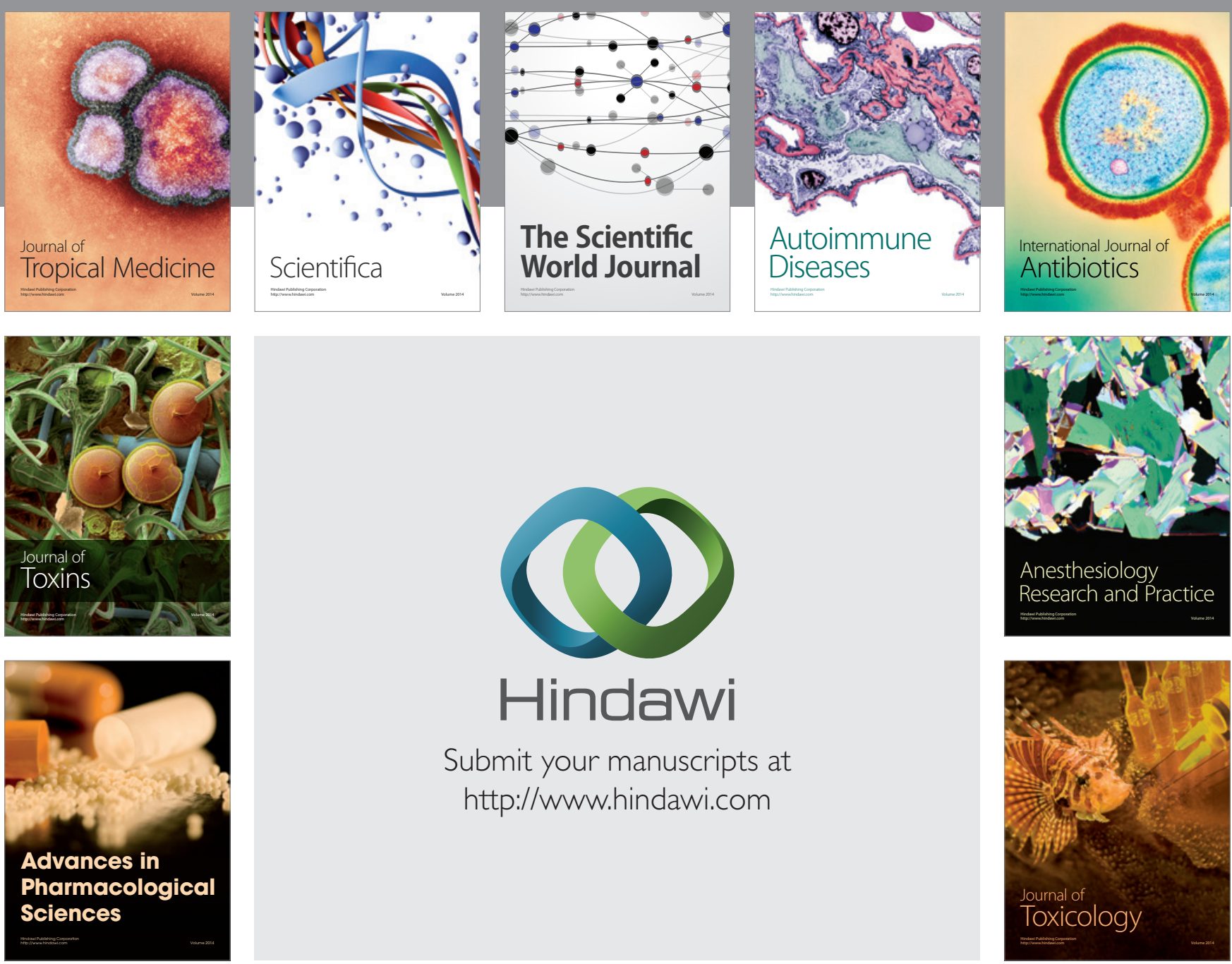

\section{Hindawi}

Submit your manuscripts at

http://www.hindawi.com
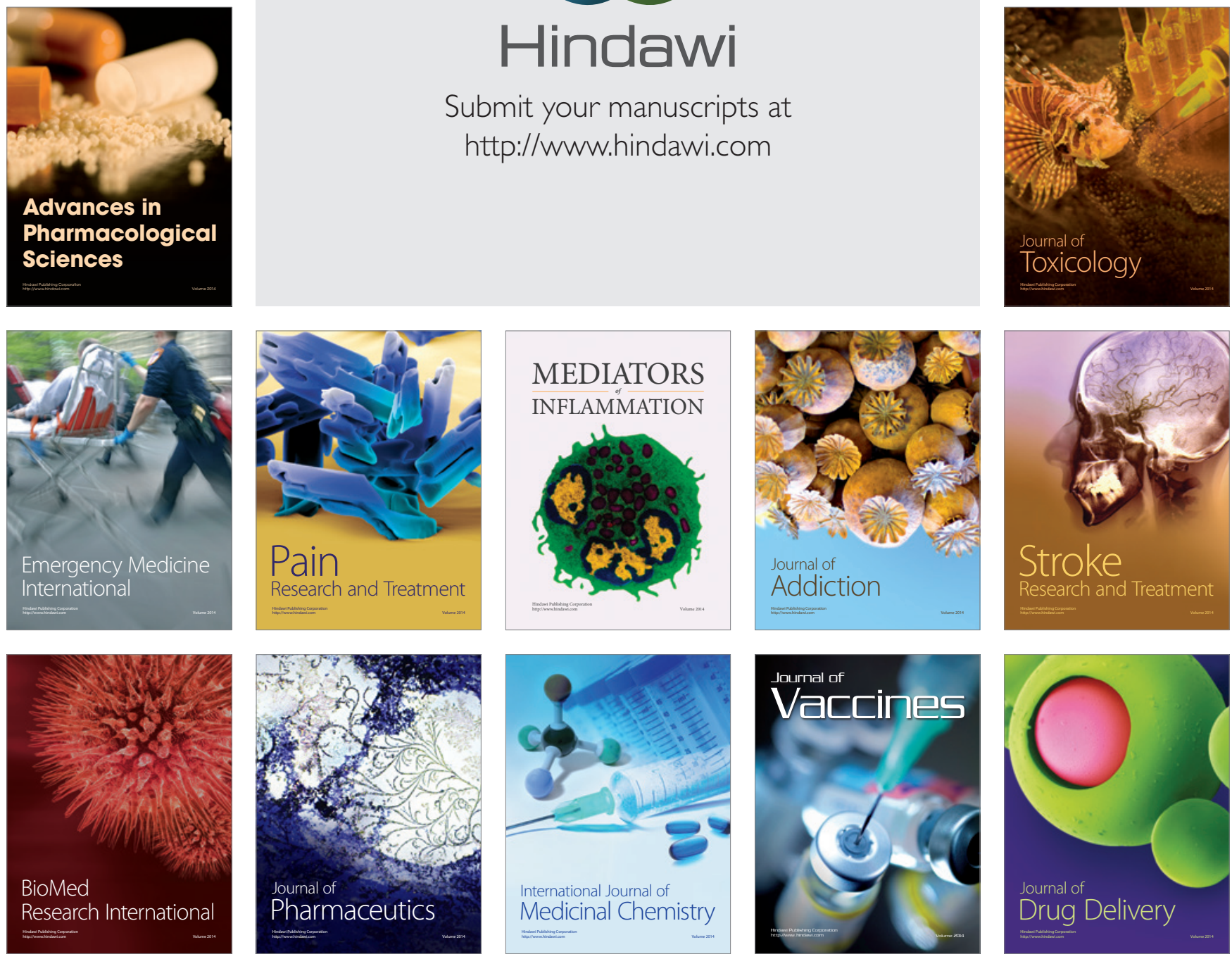